\title{
RADIOFREQUENCY ELECTROMAGNETIC RADIATION FROM WI-FI AND ITS EFFECTS ON HUMAN HEALTH, IN PARTICULAR CHILDREN AND ADOLESCENTS
}

\author{
Andrzej Magiera ${ }^{1}$, Jolanta Solecka ${ }^{l}$ \\ ${ }^{1}$ National Institute of Public Health - National Institute of Hygiene \\ Department of Environmental Health and Safety, 24 Chocimska str., 00-791 Warsaw, Poland
}

\begin{abstract}
Radiofrequency electromagnetic radiation emitted from Wi-Fi devices is nonionizing radiation. The frequencies used in wireless technology are similar to those applied in mobile telephony. Due to the much lower output power of devices using Wi-Fi compared to mobile phones, the degree of exposure to radiation is also lower. Most of the research on Wi-Fi has been carried out in less favorable or adverse conditions, involving higher power values of devices (peak values instead of average values) and smaller distances of working devices from measuring points. None of the studies conducted so far have indicated that there were the exceedances of the permissible values of radiofrequency electromagnetic radiation contained in the Polish and global legal regulations. Similar to the research related to the impact of mobile telephony on human health, the studies conducted until now focusing on exposure to Wi-Fi are considered ambiguous as they do not give a definitive answer on the possible negative (including carcinogenic) effects on human health. Because of the continuous development of wireless networks, there is a need for further research on this topic. Moreover, due to the high popularity of devices using Wi-Fi among children and adolescents, whose period of exposure to electromagnetic radiation is longer compared to adults, it is necessary to continuously observe these populations and subject them to careful analysis.
\end{abstract}

Key words: electromagnetic wave, radiofrequency radiation (RFR), Wi-Fi, health aspects

\section{STRESZCZENIE}

Promieniowanie elektromagnetyczne częstotliwości radiowych pochodzące od urządzeń korzystających z Wi-Fi jest promieniowaniem niejonizującym. Częstotliwości pracy wykorzystywane w technologii bezprzewodowej Wi-Fi są zbliżone do tych wykorzystywanych w telefonii komórkowej. Z powodu dużo niższej mocy urządzeń używających Wi-Fi w porównaniu do telefonii komórkowej, narażenie na promieniowanie jest również niższe. Większość badań dotyczących Wi-Fi przeprowadzona została w warunkach mniej korzystnych, uwzględniających wysoką moc pracujących urządzeń (wartości szczytowe zamiast wartości średnich) oraz mniejsze odległości urządzeń od punktów pomiarowych. W żadnym z przeprowadzonych dotychczas badań nie stwierdzono przekroczenia dopuszczalnych poziomów promieniowania elektromagnetycznego zawartych w polskich i światowych regulacjach prawnych. Podobnie do badań związanych z wpływem telefonii komórkowej na zdrowie ludzi, dotychczasowe badania dotyczące narażenia pochodzącego od Wi-Fi są uważane za niejednoznaczne, ponieważ nie dają ostatecznej odpowiedzi na temat możliwych negatywnych (w tym rakotwórczych) skutków dla zdrowia ludzi. Ze względu na ciągły rozwój sieci bezprzewodowych istnieje potrzeba dalszych badań. Ponadto, ze względu na dużą popularność urządzeń wykorzystujących Wi-Fi wśród dzieci i młodzieży, których okres ekspozycji na promieniowanie elektromagnetyczne jest dłuższy w porównaniu z osobami dorosłymi, konieczne jest ciągłe obserwowanie tych grup ludzi i poddawanie ich dokładnej analizie.

Słowa kluczowe: fale elektromagnetyczne, promieniowanie elektromagnetyczne częstotliwości radiowych, Wi-Fi, aspekty zdrowotne

Corresponding author: Andrzej Magiera, National Institute of Public Health - National Institute of Hygiene, Department of Environmental Health and Safety, 24 Chocimska str., 00-791 Warsaw, Poland, tel. +48 225421 423, e-mail: amagiera@pzh.gov.pl 


\section{RADIOFREQUENCY ELECTROMAGNETIC RADIATION AND ITS SOURCES IN THE ENVIRONMENT}

Radiation is the transfer of energy between an emission source and a receiver. It takes place through the transmission of particles or electromagnetic waves, without the involvement of a material medium. Electromagnetic waves can propagate not only through materials but also through a vacuum. These waves are created due to the movement of electric charge that generates an electric current, while a magnetic field appears around the resulting electric current An electromagnetic wave is characterized by several physical quantities, which include the following: electric field strength $-\mathrm{E}$ (the SI unit is $\mathrm{V} / \mathrm{m}$ ); magnetic field strength $-\mathrm{H}$ (the SI unit is $\mathrm{A} / \mathrm{m}$ ); and frequency, which refers to the number of complete electric or magnetic field changes occurring per second (the SI unit is $\mathrm{Hz}$ ) [13].

Electromagnetic radiation is inherent in an environment. The electric and magnetic fields are created naturally; for example, the constant electric field of the Earth arises from the potential difference between the negative charge of its surface and the positive charge of the ionosphere. The strength of the Earth's electric field varies between 100 and $150 \mathrm{~V} / \mathrm{m}$ [17]. Artificial electromagnetic radiation is produced due to science and technological advances and human activities [16]. Each electrical device generates an electric and a magnetic field, increasing the level of electromagnetic radiation in the environment. A few examples of the sources of electromagnetic radiation are mobile phones and the Wi-Fi devices (e.g. routers or access points). With increased technological development, the issue of radiation exposure from Wi-Fi, which currently affects the majority of the population, has become a subject of research and analysis [14]. Radiation exposure covers not only the people using emitting devices but also those in the surrounding area. This problem is even more intensified in densely populated regions, especially large cities, where the number of Wi-Fi access points is comparatively higher.

\section{LEGAL REGULATIONS IN POLAND AND WORLDWIDE}

The high prevalence of the sources generating electromagnetic radiation (including $\mathrm{Wi}$-Fi devices) in the natural environment has led to the implementation of legal regulations in Poland and worldwide for ensuring environmental protection. The basic legal act passed in Poland specifying environmental safety against radiation is the Act of 27 April 2001
- Environmental Protection Law (Journal of Law of 2019, item 1396, as amended) [24]. Pursuant to Article 122 of the Act, the levels of electromagnetic fields that can be permitted in the environment have been determined for areas intended for housing and those accessible to the public - Regulation of the Minister of Health of 17 December 2019 on permissible levels of electromagnetic fields in the environment (Journal of Law of 2019, item 2448) [18]. In the European Union, the basic legal act that was adopted for the protection of the population against electromagnetic radiation is Council Recommendation (1999/519/EC) of 12 July 1999 on the limitation of exposure of the general public to electromagnetic fields $(0 \mathrm{~Hz}$ to 300 $\mathrm{GHz}$ ) [3]. The reference levels for electromagnetic fields (electric field strength, magnetic field strength, and equivalent plane wave power density) in the whole frequency range that are set by the Polish legal regulations and the recommendation of the European Union are the same. In the frequency range from 2 to $300 \mathrm{GHz}$ (radiofrequencies also used in Wi-Fi), an electric field strength of $61 \mathrm{~V} / \mathrm{m}$ and an equivalent plane wave density of $10 \mathrm{~W} / \mathrm{m}^{2}$ are permissible. By the end of 2019, the levels of radiofrequency electromagnetic fields permitted by the Polish legal regulations became one among the most restrictive levels in Europe and in the world.

The legal acts define the basic restrictions (related to the phenomena that affect a person directly) and the reference levels (introduced to measure and evaluate the exceedances of basic restrictions). In the recommendation of the European Union, the basic restrictions are expressed by specific absorption rate (SAR) which is a measure of radiofrequency electromagnetic field absorbed by the human body (its unit is $\mathrm{W} / \mathrm{kg}$ ). As recommended in the legal acts passed by the European Union and the International Commission on Non-ionizing Radiation Protection (ICNIRP), the average SAR (for frequencies ranging from $10 \mathrm{MHz}$ to $10 \mathrm{GHz}$ ) that is permissible for the entire human body is $0.08 \mathrm{~W} / \mathrm{kg}$, with the value for exposure of the head and torso being $2 \mathrm{~W} / \mathrm{kg}$ and that of limbs being $4 \mathrm{~W} / \mathrm{kg}[3,7]$. SAR is used to determine the exposure from the devices emitting electromagnetic radiation that are at short distances from the body [6]. The determination of SAR for humans is complicated by many factors including the thermoregulation potential of the human body (tissues have the ability to put off the thermal energy supplied to the body). The reference levels are expressed by the electric field strength (E), magnetic field strength $(\mathrm{H})$, and equivalent plane wave power density $(\mathrm{S})$. The basic restrictions will not be exceeded at a place where the exposure to electromagnetic radiation is within the reference levels, regardless of the length of stay. 


\section{WI-FI}

Wi-Fi is a wireless transmission technique used for local area networking. It operates in the 2.4- and $5-\mathrm{GHz}$ radio band, which is similar to the frequencies (microwave range) used in mobile telephony. In recent years, Wi-Fi has become ubiquitous in modern society. Wi-Fi devices support wireless local area networks (WLANs). The most common and known function of these devices is to provide internet access to portable computers, but they are also applied in the case of other communication devices, including electricity meters. Wi-Fi was initially developed as a wireless replacement for Ethernet cables which were previously used to connect computers to local networks. Currently, WiFi is the basis for almost all the WLANs present in houses, offices, etc. Every modern laptop and mobile phone is equipped with Wi-Fi. In addition, domestic appliances (e.g. bathroom scales, gaming devices, audio equipment) are nowadays equipped with Wi-Fi to enable programming $[6,14]$. Moreover, using WiFi is very convenient because it allows moving and operating various mobile devices. Figure 1 presents a simple diagram of a WLAN. or domestic appliances such as microwave ovens [6]. A Wi-Fi network might also use a higher frequency range of 4.915-5.825 GHz (5 GHz) in some cases [23].

A simple model representing the propagation of electromagnetic radiation in free space can allow estimating the exposure to radiation emitted from a Wi-Fi device. In the case of an antenna emitting power $(\mathrm{P})$ (excluding reflections from other surfaces), the power density $(\mathrm{S})$ at a distance $(\mathrm{R})$ is given as:

$$
S=\frac{P G}{4 \pi r^{2}}=\frac{E I R P}{4 \pi r^{2}},
$$

where:

- $\mathrm{G}$ is the gain of the antenna (expressed in $\mathrm{dBi}$ ) which indicates the value (expressed in $\mathrm{dB}$ ) at which the antenna gain is greater in relation to the hypothetical isotropic antenna (an infinitely small point in a vacuum, emitting isotropic electromagnetic radiation in each direction without reflections or losses);

- EIRP is the effective isotropic radiated power, which is the product of power $(\mathrm{P})$ and gain of the antenna $(\mathrm{G})$ and represents the power that the isotropic antenna would have to radiate in order to get the same level of the signal in the direction of the maximum radiation of the given antenna;

- $\mathrm{R}$ is the distance from the source of electromagnetic radiation [6].

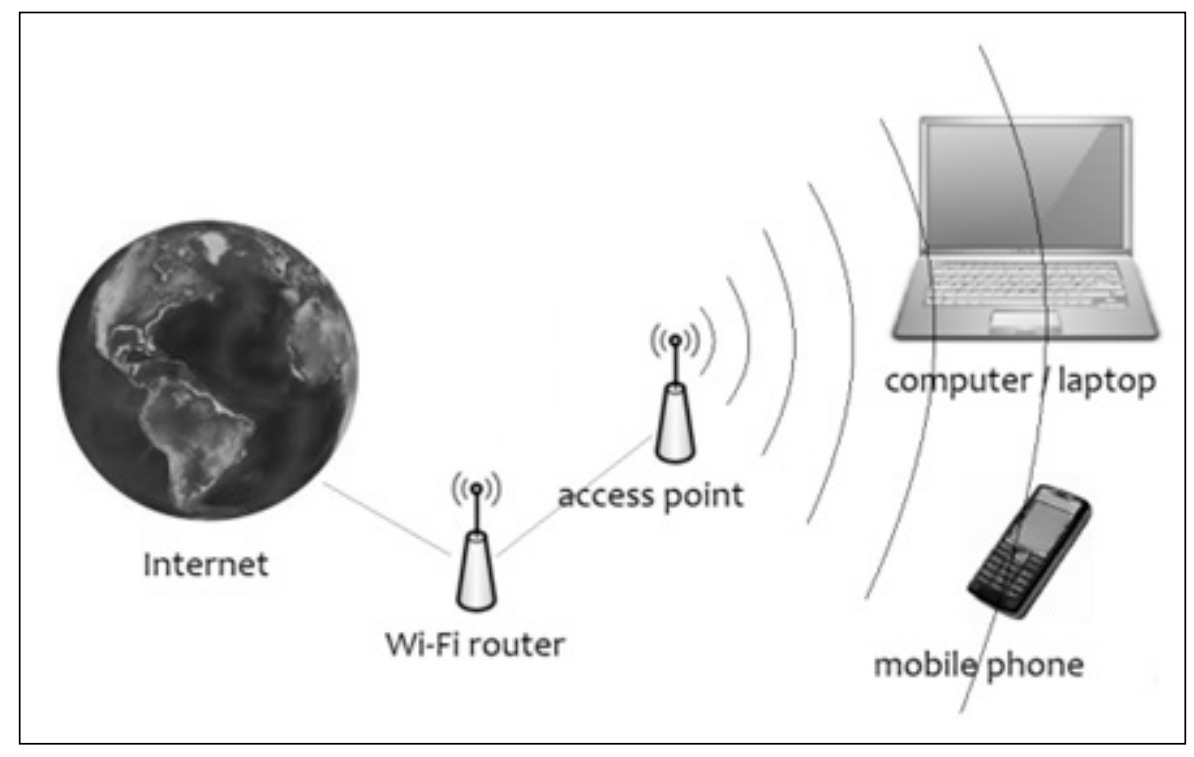

Figure 1. Wireless local area network (WLAN)

A Wi-Fi router can be integrated with an access point or can function independently. It is a device that allows connecting to a wireless network. Most Wi-Fi devices operate in the frequency range of 2.400-2.4835 $\mathrm{GHz}(2.4 \mathrm{GHz})$. For example, cell phones use a similar frequency band (the third-generation $3 \mathrm{G}$ network) of $2.1 \mathrm{GHz}$. The frequency range of Wi-Fi devices falls within the ISM (industrial-scientific-medical) band. Furthermore, the frequency band of 2.4-2.5 $\mathrm{GHz}$ is reserved for other devices, including those used for communication such as cordless telephones
For a simple lossless dipole antenna, which is typical of the antennas present in many $\mathrm{Wi}$ Fi transmitters, the antenna gain $(\mathrm{G})$ equals 1.65 . Typical Wi-Fi devices that operate at a power of approximately $0.1 \mathrm{~W}$ produce a peak power density of almost 330 and $13 \mathrm{~mW} / \mathrm{m}^{2}$ at a distance of $20 \mathrm{~cm}$ and $1 \mathrm{~m}$, respectively. The above equation does not take into account the reflections from surfaces, which is a significant phenomenon occurring during the propagation of radiofrequency electromagnetic waves inside buildings. However, it provides a fairly good 
estimate of the wave propagation taking place inside buildings for a distance of several meters from the antenna. It should be noted that real Wi-Fi transmitters work at much lower levels of power than that indicated in the above equation [6].

The actual conditions of propagation of electromagnetic waves from devices, for example, Wi-Fi routers, in indoors are different from that in free space. The electromagnetic waves encounter various obstacles, such as walls, equipment, and even humans. Moreover, physical phenomena, including wave attenuation and wave reflection or diffraction at the edges of walls, should also be taken into consideration. Table 1 shows the attenuation values of some individual building elements for the $2.4-\mathrm{GHz}$ frequency. the effects of radiation on human tissues [9]. The recent experiments that investigated the impact of electromagnetic radiation emitted from Wi-Fi devices had either of the following two objectives: assessing the exposure under normal conditions or assessing the exposure under adverse conditions (e.g. with antennas that emit electromagnetic radiation continuously or at a distance of only a few centimeters from the body). Both experimental studies and numerical simulations have been carried out, with some of them involving animals. The results of selected studies are described below.

A study conducted by Karipidis et al. in 2017 measured exposure to electromagnetic radiation from Wi-Fi and other sources at 23 schools in Australia. The mean and peak values of radiofrequency

Table 1. Attenuation values of building materials for the 2.4-GHz frequency [10]

\begin{tabular}{|c|c|c|c|}
\hline Name of the element & Material & Thickness [cm] & Attenuation [dB] \\
\hline Internal wall & Brick & 10 & 7 \\
\hline External wall & Brick & 30 & 9 \\
\hline Partition wall & Plasterboards and glass wool & 7 & 2 \\
\hline Ceiling & Concrete & 30 & 11 \\
\hline Window & Glass & $2 \times$ glass $+1 \mathrm{~cm} \mathrm{gap}$ & 4.5 \\
\hline Door & Wood & 4 & 2.5 \\
\hline
\end{tabular}

For example, a 3-dB attenuation indicates a twofold decrease in signal strength, while a 9-dB attenuation means an eightfold decrease, and an 11-dB attenuation, over a 12-fold loss of a radio signal in a given band.

Antennas that are mounted inside laptops or other devices using Wi-Fi are usually very small in size in the order of a few centimeters, which is considered to be insignificant compared to the distance between the device and the user. This suggests that exposure to electromagnetic radiation emitted by the devices rapidly decreases as the user's distance from them increases (as exposure is inversely proportional to the square of the distance). However, it is worth noting that the users are at much greater distances from devices transmitting Wi-Fi signals than when using mobile phones (distance between the head and the device) [15].

\section{RECENT STUDIES AND EXPERIMENTS ON THE IMPACT OF WI-FI ON HUMANS}

In studies carried out so far analyzing the possible negative impact of electromagnetic radiation (radioand microwave frequencies), exposure values were measured either from physical quantities such as electric field strength and equivalent plane wave power density, which are compared to the reference levels specified in the relevant legal regulations, or from SAR, which is calculated to determine electromagnetic radiation were calculated by the authors. All the measurements revealed much lower levels compared to the reference ones specified in the legal regulations-CouncilRecommendation(1999/519/ EC) of 12 July 1999 on the limitation of exposure of the general public to electromagnetic fields $(0 \mathrm{~Hz}$ to $300 \mathrm{GHz}$ ). The values measured in empty classrooms and classrooms with students constituted from about $0.0001 \%$ (average) to about $0.01 \%$ (peak) of the limit values recommended by the European Council. The levels of exposure to electromagnetic radiation from Wi-Fi determined in the study were found to be much lower than those estimated for other working devices, such as radio, television, or mobile phones [11].

In another study conducted by Peyman et al. in 2011, the level of electromagnetic radiation (electric field strength) released from a total of 15 working laptops and 12 access points at UK schools was measured. The maximum values of this physical quantity at a distance of $0.5 \mathrm{~m}$ from the devices - laptops and Wi-Fi routers - were estimated to be 2.893 and 5.716 $\mathrm{mV} / \mathrm{m}$, respectively. These values represented $0.005 \%$ and $0.01 \%$, respectively, of the reference levels recommended in the European Union. At a distance of $0.5 \mathrm{~m}$, the equivalent plane wave power density was calculated as $22 \mathrm{~mW} / \mathrm{m}^{2}$ for laptops and $87 \mathrm{~mW} / \mathrm{m}^{2}$ for Wi-Fi access points. Moreover, these did not exceed the recommended values and constituted $0.22 \%$ and $0.87 \%$ of the reference levels specified in the Polish 
and European legal regulations. Measurements were also made with respect to other distances (greater than $0.5 \mathrm{~m}$ ), which showed that for a twofold increase in the distance $(1 \mathrm{~m})$, the values of equivalent plane wave power density decreased by about four times [15]. This finding is consistent with the fact that the decrease in the level of radiation depends on the distance from its source.

In 2007, Foster [5] conducted a study on the effects of electromagnetic radiation emitted from Wi-Fi in different environments and in various countries. A total of 365 measurements were taken in 55 cities of four countries (United States of America, France, Germany, and Sweden), in places occupied by people, such as offices, shops, and healthcare facilities. Measurements made at short distances from devices (1 $\mathrm{m}$ from laptops that use $\mathrm{Wi}-\mathrm{Fi}$ ) showed exposure levels that were much lower than those recommended in the international legal regulations. In addition, the measurements were taken while large files were downloaded (during which time the devices work at the highest power). However, it was found that the level of electromagnetic radiation (expressed by equivalent plane wave power density) was much lower than that contained in the Polish and international legal regulations. The measurements ranged from 0.001 to $0.01 \mathrm{~W} / \mathrm{m}^{2}$, which constitutes from $0.01 \%$ to $0.1 \%$ of the limit values, respectively.

Another study was carried out by Schmid et al. [20] in 2007 under the normal operating conditions of devices using WLANs in closed rooms such as cafes, airports, and open space (including public places with Internet access - downtown and residential area) in Germany. All the measured values of equivalent plane wave power density were several orders of magnitude lower than the limit values. It was found that even for a distance of $20 \mathrm{~cm}$ (for cafes), the measured values did not exceed the recommended limits. Similarly, in the case of open space (where the distances from the devices are much greater), the values measured were within the reference levels and were much lower than the measurements taken in rooms. Table 2 shows the results of these measurements.
In 2010, Findlay and Dimbylow [4] conducted an experiment on a voxel phantom (computer-simulated human body) of a ten-year-old child. Exposure to electromagnetic radiation from Wi-Fi devices was simulated - for the frequencies of 2.4 and $5 \mathrm{GHz}$. In all the measurements made in the experiment, the SAR values were found to be significantly lower than those specified in the relevant legal regulations. The highest measured SAR value for the whole body was $19.1 \mu \mathrm{W} / \mathrm{kg}$ (normalized value for $1 \mathrm{~V} / \mathrm{m}$ ). It was determined that in order to exceed the SAR limit (i.e. $0.08 \mathrm{~W} / \mathrm{kg}$ for the whole body), a person should be exposed to electromagnetic radiation with an electric field strength of $64.7 \mathrm{~V} / \mathrm{m}$. Typical values of electric field strength measured at a distance of $1 \mathrm{~m}$ from Wi-Fi access points were below $2 \mathrm{~V} / \mathrm{m}$, which were so much lower than those at which SAR would be exceeded. SAR values were also measured depending on the distance from the antenna for the head and torso. Even at the smallest distances (in the study, the head-antenna distance was $3 \mathrm{~cm}$ ), the maximum SAR value measured was $81.7 \mathrm{~mW} / \mathrm{kg}$. The $\mathrm{SAR}$ value was calculated taking into account a factor of $1 / 10$ for laptop Wi-Fi antennas (assuming that 10 people use an access point simultaneously) and typical WiFi antenna power, which does not exceed $100 \mathrm{~mW}$, which showed an average power of $10 \mathrm{~mW}$ for laptop Wi-Fi antennas. The SAR values recommended by ICNIRP for the head are $2 \mathrm{~W} / \mathrm{kg}$; therefore, the values measured in the study were below the one mentioned in the guidelines (they represent a maximum of $4 \%$ of the limit values). All the SAR measurements carried out at different distances during the use of a computer with Wi-Fi access were not found to be exceeded and were significantly lower than those allowed in legal regulations.

In addition to the experiments carried out under the normal (standard) operating conditions of devices using Wi-Fi, some were carried out in more adverse conditions. These evaluated the exposure to electromagnetic radiation from devices that were very close to the measuring points (as if they were close to the user's body) or worked at maximum (or much higher than normally used) power. In a study conducted by

Table 2. Maximum measured values of equivalent plane wave power density at various measuring points [20]

\begin{tabular}{|c|c|c|c|}
\hline Measurement location & $\begin{array}{c}\text { Minimum distance from } \\
\text { the antenna }[\mathrm{m}]\end{array}$ & $\begin{array}{c}\text { Maximum measured values } \\
\text { of equivalent plane wave } \\
\text { power density }\left[\mathrm{mW} / \mathrm{m}^{2}\right]\end{array}$ & $\begin{array}{c}\text { The share of the measured } \\
\text { value in relation to the limit } \\
\text { value-10,000 } \mathrm{mW} / \mathrm{m}^{2}\end{array}$ \\
\hline Cafe & 0.2 & 183 & $1.83 \%$ \\
\hline Airport & 3.0 & 1.86 & $0.0186 \%$ \\
\hline Outdoor 1-downtown & 5.0 & 0.10 & $0.001 \%$ \\
\hline Outdoor 2-downtown & 5.0 & 0.34 & $0.0034 \%$ \\
\hline Outdoor 1-residential area & 50.0 & 0.002 & $0.00002 \%$ \\
\hline Outdoor 2-residential area & 50.0 & 0.004 & $0.00004 \%$ \\
\hline
\end{tabular}


Kuhn et al. in 2007, the levels of electric field strength and SAR values for $100 \mathrm{~cm}$ from the device using WiFi were estimated under the worst possible operating conditions (devices worked at maximum power). In the case of $\mathrm{Wi}$-Fi routers operating in the frequency range of $2.400-2.484 \mathrm{GHz}$, the electric field strength was 1.1 $\mathrm{V} / \mathrm{m}$, while for a frequency of $5.200-5.800 \mathrm{GHz}$, the strength equaled $0.9 \mathrm{~V} / \mathrm{m}$. The SAR values were 0.36 and $0.81 \mathrm{~W} / \mathrm{kg}$, respectively, which did not exceed the reference levels and basic restrictions. Close proximity to this type of equipment can be avoided by mounting them on the wall above users' heads [12].

In a study conducted by Schmid et al. in 2007, video surveillance systems for babies, Digital Enhanced Cordless Telecommunications (Digital European Cordless Telecommunications) - DECT, devices using the Bluetooth function, and WLANs were analyzed. The values of equivalent plane wave power density measured did not exceed the limit values in any of the checked points, and constituted a maximum (for average values) of $0.004 \%$ of the limit values [19]. In the same experiment, the SAR values for use under very unfavorable conditions were also measured for selected devices, including those using a WLAN (the device emitting electromagnetic radiation from the antenna was in contact with the phantom surface where the SAR level was measured). For a laptop using $\mathrm{Wi}-\mathrm{Fi}$, the maximum SAR value was found to be 0.05 $\mathrm{W} / \mathrm{kg}$ which was lower than the limit value for limbs (4 $\mathrm{W} / \mathrm{kg})$ and that for the head and torso $(2 \mathrm{~W} / \mathrm{kg})[3,7]$.

In addition to numerous studies carried out over the years, in which the physical quantities related to exposure to high-frequency electromagnetic radiation were measured in various places and under different operating conditions of devices using Wi-Fi (antennas on laptops, Wi-Fi routers, access points), experiments involving living organisms such as animals and humans have also been conducted, investigating the effects of electromagnetic radiation on their behaviors and biological functions.

Studies focusing on the effects of long-term exposure to electromagnetic radiation from $\mathrm{Wi}-\mathrm{Fi}$ signals (a frequency of $2.4 \mathrm{GHz}$ ) were carried out by Banaceur et al. [2] in 2013 using mice. The animals were exposed to radiation to reach an SAR of $1.6 \mathrm{~W} / \mathrm{kg}$ for 2 hours a day for 1 month. The results of the study showed that exposure to electromagnetic radiation can improve memory in animals with Alzheimer's disease and also improve cognitive abilities.

Shokri et al. [21] conducted an experiment in 2015 on rats. The study animals were divided into three groups: the first group (control) which consisted of nine healthy individuals was not exposed to electromagnetic radiation from antennas (Wi-Fi devices), the second group which consisted of nineindividuals was irradiated with electromagnetic radiation at a frequency of 2.45
GHz for 1 hour a day for 2 months, and the third group which consisted of nine individuals was irradiated with $2.45-\mathrm{GHz}$ electromagnetic radiation for 7 hours a day for 2 months. The results of the study showed that depending on the length of exposure (the longer the exposure, the greater the negative impact), the quality of sperms in male rats deteriorated (with the worst quality observed in the third group). The study also showed the relationship between the other health effects and the time of exposure to the high-frequency electromagnetic radiation. The authors concluded that the effects of exposure of our body to electromagnetic radiation emitted from Wi-Fi antennas are timedependent [21]. However, as a very small number of animals were tested in the study, the obtained results are considered unreliable.

A study conducted by Hassanshahi et al. in 2017 aimed to assess the impact of chronic exposure to electromagnetic radiation from $\mathrm{Wi}-\mathrm{Fi}$ devices on learning ability in rats. The results showed that Wi-Fi signals impair the ability of animals to distinguish between a new and a known object. As this finding indicated a possible adverse effect of the electromagnetic radiation from $\mathrm{Wi}-\mathrm{Fi}$, it might be particularly interesting to analyze the potential effects of Wi-Fi on cognitive behaviors in both animals and humans [8].

Most studies on animals conducted thus far have shown the negative effects of electromagnetic radiation. However, they report contrasting results. Undoubtedly, electromagnetic radiation is related to the absorption of energy by living organisms. Thus, it can be emphasized that changes can be observed in the hormone levels or in the activity of the nerve ending of the brain in the organisms that are exposed to highfrequency electromagnetic radiation (with SAR values not causing thermal effects). With higher SAR values (about $6.8 \mathrm{~W} / \mathrm{kg}$ ), a significant shortening of the life expectancy can be expected in the examined animals.

Table 3 presents some examples of biological effects caused by high-frequency electromagnetic radiation for various organisms depending on the SAR value.

After absorbing low energies of electromagnetic radiation (before body temperature rises), thermoregulatory mechanisms can reduce the heat energy. In primates, behavioral changes may occur with reduction of locomotor activity or delay of reaction time. The limit values for the behavioral changes mentioned above are only indicative [22]. Research results reported to date have shown the high-frequency electromagnetic radiation as a weak biological factor $[16,17]$.

Due to ethical reasons, studies on the effects of radiofrequency electromagnetic radiation on human health are difficult to conduct. Moreover, ensuring the right conditions (full power range of working devices, 
Table 3. Examples of biological effects caused by high-frequency electromagnetic radiation [17, 22]

\begin{tabular}{|l|l|c|c|}
\hline \multicolumn{1}{|c|}{ Type of biological effect } & Research subject & $\begin{array}{c}\text { SAR } \\
{[\mathrm{W} / \mathrm{kg}]}\end{array}$ & $\begin{array}{c}\text { Temperature } \\
\text { increase }\left[{ }^{\circ} \mathrm{C}\right]\end{array}$ \\
\hline Cataract & Rabbits & $100-150$ & $3-6$ \\
\hline Congenital abnormalities & Rats & $6-10$ & $2-3$ \\
\hline Hormonal responses & Rats, primates & $3-4$ & $1-2$ \\
\hline Impaired performance of learned activities & Rats, primates & $2-5$ & 1 \\
\hline Reduction of locomotor activity & Primates & $1-3$ & $<1$ \\
\hline Activation of thermoregulatory mechanisms & Primates & $0.7-1$ & $<1$ \\
\hline Decreased metabolism & Primates & $0.7-1$ & $<1$ \\
\hline Auditory hallucinations & Humans, rats & $0.01-0.1$ & - \\
\hline Electrocardiography changes & Rabbits & $0.01-0.5$ & - \\
\hline Increased permeability of the blood-brain barrier & Rats, rabbits & $0.05-0.1$ & - \\
\hline
\end{tabular}

testing the same population for many years) is also challenging [16]. Therefore, it is only possible to carry out experiments on animals or on cell cultures. However, each of them may have some disadvantages. In addition, it is not known if conclusions can be drawn from animal studies and generalized directly to humans. Therefore, many of the studies conducted are considered ambiguous.

In a recent study carried out on humans by Hosseini in 2019, the possible impact of short-term Wi-Fi signals on the cognitive functions of the brain was analyzed. Consent for the study was obtained from the local Ethics Committee of Shiraz University of Medical Sciences in Iran, and the study was approved by the Iranian Registry of Clinical Trials. A total of 45 students from Shiraz University participated in the experiment which had two sessions: one involving exposure to electromagnetic radiation from $\mathrm{Wi}-\mathrm{Fi}$ and the other without exposure (sham). Each session lasted two hours. After the session, the participants were subjected to reaction time test, short-term memory test, and reasoning skills test. No statistically significant differences were found between the average results of reaction time, short-term memory, and reasoning ability in both sessions (sham and exposure). During the experiment, the reference levels - electric field strength and equivalent plane wave density - were also measured. At a distance of $1.5 \mathrm{~m}$ and a height of $1.2 \mathrm{~m}$ (typical when using Wi-Fi devices), the values were calculated to be, respectively, $4.1 \mathrm{~V} / \mathrm{m}$ and 0.0446 $\mathrm{W} / \mathrm{m}^{2}$ [9], which constituted $7 \%$ of the limit value for the electric field strength recommended in most of the countries of the European Union and $0.4 \%$ of the limit value for equivalent plane wave density.

Since the $1950 \mathrm{~s}$, many studies have been conducted on the biological effects of radiofrequency electromagnetic radiation on living organisms. These have assessed both the impact of mobile phones and Wi-Fi. However, so far, none of them have shown that there is proven risk associated with the operation of these devices, as long as the limits (basic restrictions and reference levels) specified in the relevant legal regulations are not exceeded $[1,6]$.

\section{SUMMARY}

Radiofrequency electromagnetic radiation is nonionizing radiation, which cannot affect the structures or molecules present in the biological systems as their energies are too low. However, highfrequency electromagnetic radiation can possibly cause, among others, an increase in tissue temperature (thermal effect).

When examining the impact of electromagnetic radiation from Wi-Fi devices, it should be noted that the output power resulting from a Wi-Fi router is much lower than that from mobile phones. In addition, both cell phones and Wi-Fi devices work in similar frequency ranges. Therefore, the degree of exposure to electromagnetic radiation from WiFi is lower compared to mobile phones. Moreover, Wi-Fi routers are located at much greater distances from the human body than mobile phones, which are usually present at a few centimeters from the body or right next to the head. With the continuous progress of science and technology, higher frequencies of electromagnetic radiation are applied. However, the higher the frequency, a greater part of the radiation is absorbed by the human skin and a lesser part reaches the internal organs.

Most of the research related to the exposure to electromagnetic radiation from Wi-Fi has been carried out in adverse conditions (higher power values - peak values instead of average values, distances shorter than real). However, the results showed that the measured levels did not exceed the limit values contained in various legal regulations around the world. The biggest difficulty in interpreting and drawing conclusions from animal studies is to estimate the possible effects on human health using their results. For this reason, 
many of the studies conducted so far are considered ambiguous as they do not give a definitive answer about the possible negative impact on human health. Due to the continuous development of wireless networks, there is a need to conduct further research on this topic.

Wi-Fi devices (including routers) came into existence only about $15-20$ years ago. However, they have become ubiquitous in the modern world. Due to their high popularity among children and young people who are known to have a longer period of exposure (than adults) to radiofrequency electromagnetic radiation, these populations should be subjected to careful analysis. Despite the lack of unambiguous evidence for the carcinogenic effect of radiofrequency electromagnetic radiation, in recent years, several harmful environmental factors are identified to be detrimental to human health. Therefore, it is necessary to analyze whether the overlap of some of these harmful factors can cause deterioration of health and increase the risk of morbidity (e.g. cancer).

\section{Conflict of interest}

The authors declare no conflict of interests.

\section{Acknowledgements}

This work was financially supported by the National Institute of Public Health-National Institute of Hygiene in Warsaw, Poland, in the frame of project No $B K-1 / 2020$.

\section{REFERENCES}

1. AGNIR. 2012, Health Effects from Radiofrequency Electromagnetic Fields. Report of the Advisory Group on Non-ionising Radiation. Doc HPA, London: Health Protection Agency, RCE-20, 2012, Available: https:// assets.publishing.service.gov.uk/government/uploads/ system/uploads/attachment_data/file/333080/RCE20_Health_Effects_RF_Electromagnetic_fields.pdf (Accessed 22.06.2020)

2. Banaceur S., Banasr S., Sakly M., Abdelmelek H.: Whole body exposure to $2.4 \mathrm{GHz}$ WIFI signals: effects on cognitive impairment in adult triple transgenic mouse models of Alzheimer's disease (3xTg-AD). Behav Brain Res. 2013 Mar 1;240:197-201. doi: 10.1016/j. bbr.2012.11.021

3. Council Recommendation of 12 July 1999 on the limitation of exposure of the general public to electromagnetic fields (0 Hz to $300 \mathrm{GHz}$ ) (1999/519/EC)

4. Findlay R., Dimbylow P.J.: SAR in a child voxel phantom from exposure to wireless computer networks (Wi-Fi). Phys Med Biol. 2010 Aug 7;55(15):N405-11. doi:10.1088/0031-9155/55/15/N01

5. Foster K.R.: Radiofrequency exposure from wireless LANs utilizing Wi-Fi technology. Health Phys. 2007 Mar;92(3):280-9, doi: 10.1097/01. HP.0000248117.74843.34
6. Foster K. R., Moulder J. E.: Wi-Fi and health: review of current status of research. Health Phys., 2013, 105(6): 561-75, doi:10.1097/HP.0b013e31829b49bb

7. Guidelines for limiting exposure to time-varying electric, magnetic, and electromagnetic fields (up to $300 \mathrm{GHz}$ ). International Commission on Non-Ionizing Radiation Protection. Health Phys. 1998 Apr;74(4):494522. Available https://www.icnirp.org/cms/upload/ publications/ICNIRPemfgdl.pdf (Accessed 21.02.2020)

8. Hassanshahi A., Shafeie S. A., Fatemi I., Hassanshahi E., Allahtavakoli M., Shabani M., Roohbakhsh A., Shamsizadeh A.: The effect of Wi-Fi electromagnetic waves in unimodal and multimodal object recognition tasks in male rats. Neurol Sci. 2017 Jun;38(6):10691076, doi:10.1007/s10072-017-2920-y

9. Hosseini M.A., Hosseini A., Jarideh S., Argasi H., Shekoohi-Shooli F., Zamani A., Taeb S., Haghani M.: Evaluating short-term exposure to Wi-Fi signals on students' reaction time, short-term memory and reasoning ability. Radiation Protection Dosimetry, 2019, doi:10.1093/rpd/ncz162

10. JasińskiŁ.: Analizaiporównaniemodelipropagacyjnych dla środowiska wewnątrzbudynkowego, 2011. Available https://docplayer.pl/16169631-Analiza-iporownanie-modeli-propagacyjnych-dla-srodowiskawewnatrzbudynkowego.html (Accessed 21.02.2020)

11. Karipidis K., Henderson S., Wijayasinghe D., Tjong L., Tinker R.: Exposure to Radiofrequency Electromagnetic Fields From Wi-Fi in Australian Schools. Radiat Prot Dosimetry, 2017, 175(4): 432-439, doi: 10.1093/rpd/ ncw370

12.Kuhn S., Lott U., Kramer A., Kuster N.: Assessment Methods for Demonstrating Compliance With Safety Limits of Wireless Devices Used in Home and Office Environments, IEEE Transactions on Electromagnetic Compatibility. September 2007;3(3):519-525, doi:10.1109/TEMC.2007.903042

13. Magiera A., Solecka J., Mobile telephony and its effects on human health, Rocz Panstw Zakl Hig. 2019;70(3):225234, doi: 0.32394/rpzh.2019.0073

14. Mamrot P., Mariańska M.: Pola elektromagnetyczne w otoczeniu routerów Wi-Fi. Prz. Telekomunikacyjny -Wiad. Telekomunikacyjne, 2015, 4, 213-216

15.Peyman A., Khalid M., Calderon C., Addison D., Mee T., Maslanyj M., Mann S., Assessment of exposure to electromagnetic fields from wireless computer networks (wi-fi) in schools; results of laboratory measurements, Health Phys. 2011 Jun;100(6):594-612. doi:10.1097/ HP.0b013e318200e203

16.Politański P., Bortkiewicz A., Zmyślony M.: Wpływ pól elektromagnetycznych zakresu radiowego i mikrofalowego, emitowanych przez urządzenia łączności bezprzewodowej, na funkcjonowanie wybranych elementów układu nerwowego, Medycyna Pracy 2016; 67(3):411-421, doi: https://doi.org/10.13075/ mp.5893.00343

17. Rochalska M.: Wpływ pól elektromagnetycznych na organizmy żywe: rośliny, ptaki, zwierzęta, Med. Pr. 2007;58(1):37-48. Available http://www.imp.lodz.pl/ upload/oficyna/artykuly/pdf/full/2007/01-Rochalska. pdf (Accessed 21.02.2020) 
18. Rozporządzenie Ministra Zdrowia z dnia 17 grudnia 2019 r. w sprawie dopuszczalnych poziomów pól elektromagnetycznych w środowisku (Dz. U. z 2019 r., poz. 2448) [Regulation of the Minister of Health of 17 December 2019 on permissible levels of electromagnetic fields in the environment Journal of Laws of 2019, item 2448)].

19. Schmid G., Lager D., Preiner P., Uberbacher R., Cecil $S$.: Exposure caused by wireless technologies used for short-range indoor communication in homes and Office, Radiat Prot Dosimetry. 2007;124(1):58-62. Epub 2007 Jun 11, 10.1093/rpd/ncm 245

20.Schmid G., Preiner P., Lager D., Uberbacher R., Georg $R$. : Exposure of the general public due to wireless LAN applications in public places, Radiat Prot Dosimetry. 2007;124(1):48-52. Epub 2007 Jun 11, doi:10.1093/rpd/ ncm 320.

21. Shokri S., Soltani A., Kazemi M., Sardari D., Mofrad F. $B$., Effects of Wi-Fi $(2.45 \mathrm{GHz})$ Exposure on Apoptosis, Sperm Parameters and Testicular Histomorphometry in Rats: A Time Course Study, Cell J. 2015 Summer; 17(2): 322-331, doi: 10.22074/cellj.2016.3740

22.Sokolska G., Szmigielski S.: Efekty biologiczne pól radio i mikrofalowych $\mathrm{w}$ badaniach doświadczalnych.
Materiały konferencyjne Szkoły Jesiennej „Wpływ fal elektromagnetycznych na organizmy żywe"; 18-22 października 1993; Zakopane, Polskie Towarzystwo Badań Radiologicznych, Warszawa 1993: 101-122.

23. Szulewski P., Ostrowski I.: Wstępna analiza możliwości zastosowania sieci $\mathrm{WiFi}$ do komunikacji z robotem mobilnym w środowisku przemysłowym, Gospodarka Materialowa \& Logistyka, 2015;(4):5180-5187. Available: https://www.researchgate.net/profile/ Piotr_Szulewski/publication/331439625_Wstepna analiza_mozliwosci_zastosowania_sieci_WiFi_do_ komunikacji_z_robotem_mobilnym_w_srodowisku_przemyslowym/links/5c7956f8299bf-1268d308135/ Wstepna-analiza-mozliwosci-zastosowania-sieci-WiFido-komunikacji-z-robotem-mobilnym-w-srodowiskuprzemyslowym.pdf (Accessed 21.02.2020)

24. Ustawa z dnia 27 kwietnia 2001 r. Prawo ochrony środowiska ( z 2019 r., poz. 1396) [Act of 27 April 2001. Environmental Protection Law (Journal of Laws of 2019, item 1396)]

Received: 14.05.2020

Accepted: 16.06 .2020 